\title{
Analasis Kinerja Portofolio Saham Dengan Indeks Sharpe Jensen dan Treynor Pada Perusahaan Subsektor Rokok Periode 2015
}

\author{
Titin Kartini \\ Fakultas Ilmu Administrasi Universitas Subang \\ titin.unsub@gmail.com
}

\begin{abstract}
Abstrak
Tujuan dilakukannya penelitian ini adalah untuk mengetahui kinerja perusahaan yang tergabung dalam subsektor rokok melalui Indeks Sharpe, Jensen dan Treynor, sehingga dapat membantu investor didalam pengambilan keputusan investasi yang tepat. Objek penelitian ini dilakukan pada saham subsektor rokok tahun 2015. Sampel yang digunakan berdasarkan perusahaan rokok menurut sahamok. Metode deskriptif digunakan untuk menggambarkan hasil dari data yang telah diolah untuk menjawab permasalahan yang ada. Berdasarkan hasil penelitian dan analisis yang telah dilakukan, dapat diketahui bahwa dari 3 saham perusahaan subsektor rokok yang dijadikan sebagai sampel penelitian, hanya saham perusahaan HMSP yang memberikan keuntungan berdasarkan perhitungan menggunakan ketiga metode, sehingga keputusan yang harus diambil oleh investor adalah membeli saham tersebut sebelum harganya undervalue.
\end{abstract}

Kata kunci: Sharpe, Jensen, Treynor

\section{Abstract}

The purpose of this study is to determine the performance of companies incorporated in the cigarette subsector through the Sharpe Index, Jensen and Treynor, so that it can help investors in making the right investment decisions. The object of this study was conducted on the cigarette subsector stock in 2015. The sample used is based on cigarette companies according to stocks. Descriptive method is used to describe the results of data that has been processed to answer existing problems. Based on the results of research and analysis that has been done, it can be seen that from the 3 shares of the cigarette subsector company that are used as research samples, only HMSP company shares that provide benefits based on calculations using the three methods, so the decision to be taken by investors is to buy these shares before the price undervalue.

Keywords: Sharpe, Jensen, Treynor 


\section{Pendahuluan}

Dengan mengevaluasi kinerja portofolio akan memungkinkan investor mengidentifikasi apakah portofolio yang telah terbentuk mampu memberikan tingkat return yang relative lebih tinggi dibandingkan dengan return portofolio lainnya dan apakah return tersebut juga sesuai dengan tingkat resiko yang ditanggung. Kinerja sebuah portofolio tidak hanya bisa melihat tingkat return yang dihasilkan, tetapi juga tetap dengan memperhatikan faktor lain seperti tingkat resiko portofolio tersebut.

Penelitian ini ingin mengetahui bagaimana kinerja portofolio dengan menggunakan ukuran sharpe, treynor, dan Jensen berdasarkan peringkat kinerja portofolio yang dibentuk pada masing-masing indek, apakah terdapat perbedaan peringkat ataukah memperlihatkan hasil yang sama antara ketiga alat ukur kinerja portofolio, dari hasil pemeringkatan tersebutdiharapkan dapat memberikan gambaran pada para investor yang mana yang dapat diinvestasikan. Metode sharpe, treynor dan Jensen dapat digunakan dalam pemilihan investasi berdasarkan analisisnya pada return masa lalu untuk memprediksi return dan resiko di masa datang. Metode sharpe menekankan pada resiko total (devisi standar), treynor memperhitungkan variabel pasar dapat mempengaruhi return (beta), dan terakhir indek jensen sendiri menekankan pada alpha. Jadi ketiga metode tersebut mempunyai karakteristik tersendiri.

Pengukuran kinerja portofolio dalam metode sharpe, treynor, dan Jensen akan memiliki karakteristik angka indeks yang berbeda satu sama lain, sehingga tidak dapat dibandingkan satu sama lainnya secara langsung seingga diperlukan standarisasi ukuran kinerja. Dengan melihat latar belakang diatas maka dilakukan penelitian lebih lanjut tentang kinerja dari portofolio yang terdiri dari sahamsaham subsektor rokok dengan menggunakan ukuran Sharpe (RVAR), Treynor (RVOL), dan Jensen (ALPHA). Tujuan yang mendasar dari portofolio adalah untuk mendapatkan alokasi yang optimal diantara aktiva-aktiva yang berbeda. Portofolio diartikan sebagai rangkaian kombinasi beberapa aktiva yang akan diinvestasikan dan dipegang oleh investor, baik perorangan maupun lembaga. Kombinasi tersebut dapat berupa aktiva rill berupa emas, perak, real assets maupun aktiva finansial berupa surat-surat berharga, bukti kepemilikan suatu perusahaan atau saham. Dengan membentuk portofolio diharapkan para investor dapat meraih return optimal dan memperkecil risk (Sumariyah, 1997).

Berdasarkan kesediaan dalam menanggung resiko, dikenal ada 3 jenis resiko yaitu berani mengambil resiko (risk taker), sikap netral terhadap resiko (risk neutral), dan yang tidak berani mengambil resiko (risk averse). Risk taker adalah sikap seseorang yang memilih taruhan yang fair sedangkan risk neutral seseorang bersikap indifference terhadap taruhan yang fair sedangkan risk averse adalah investor akan menolak taruhan yang fair (Husnan, 2003). Jenis resiko ini menyebabkan mempunyai preferensi yang berbeda dalam melihat portofolio, tidak hanya itu, preferensi dari investor akan resiko dari suatu portofolio berbeda juga satu sama lainnya. Ada yang melihat resiko total dari suatu portofolio atau melihat hanya pada beta.

Hal ini menyebabkan para pengamat juga memproyeksikan berbagai sector bisnis yang sangat menjanjikan dn bakal booming di tahun tersebut, salah satunya 
sector bisnis yang diprediksi bakal menjanjikan pada investasi portofolio (reksadana, saham, dan obligasi). Oleh sebab itu prtofolio baik yang dilakukan manajer investasi maupun investor individu akan sangat penting dalam melakukan evaluasi terhadap kinerja portofolio yang teah disusun sebelumnya untuk mengetahui tingkat pengembaliaan yang dicapai. Ada beberapa penelitian yang dilakukan sebelumnya, mengenai pengukuran kinerja portofolio menggunakan metode sharpe, treynor, dan Jensen. Salah satunya, penelitian yang dilakukan jobson dan korkie tahun 1981 menujukan hasil bahwa sharpe dan Jensen menunjukan kinerja yang baik pada data bulanan dan sampel yang kecil sedangkan treynor tidak menunjukan kinerja yang baik pada sampe yang kecil dengan menggunakan alat analisis-test.

\section{Kerangka Teori}

1) Ukuran Kinerja Sharpe

Sharpe menyatakan series kinerja portofolio dihitung merupakan hasil bersih dari portofolio dengan tingkat bunga bebas risiko per unit risiko dengan diberi simbol Sp. Indeks kinerja Sharpe dihitung dengan formula sebagai berikut yang diambil dari wijaya 2014:

$$
S p=\frac{R p-R f}{\sigma p}
$$

- Keterangan:

- $\mathrm{Sp}=$ indeks kinerja Sharpe.

- $\mathrm{Rp}=$ return portofolio.

- $\mathrm{Rf}=$ return bebas risiko.

- $\quad p=$ total risiko yaitu hasil jumlah dari risiko sistematik dan risiko unsistematik.

Kriteria yang digunakan adalah semakin tinggi indek Sharpe berarti menunjukan bahwa kinerja perusahaan semakin baik.

2) Ukuran Kinerja Treynor

Dikembangkan oleh Jack Treynor, dengan asumsi yang digunakan adalah sama dengan indek Sharpe yang berarti bahwa semakin besar indek Treynor menunjukkan kinerja perusahaan yang semakin baik.

- Keterangan:

$$
\mathbf{T p}=\frac{\mathbf{R p}-\mathbf{R f}}{\boldsymbol{\beta p}}
$$

- $\mathrm{Tp}=$ indeks kinerja Treynor.

- $R p=$ return portofolio.

- $\mathrm{Rf}=$ return bebas risiko.

- $\quad p=$ risiko pasar dari portofolio atau risiko sistematik portofolio.

3) Ukuran Kinerja Jensen

Indek Jensen menggambarkan bahwa portofolio yang dibentuk oleh investor dapat memberikan return yang lebih besar dibandingkan dengan pasar.

- Keterangan:

$$
\mathbf{a p}=\mathbf{R p}-[\mathbf{R f}+\mathbf{b p}(\mathbf{R m}-\mathbf{R f})]
$$

- $a p=$ indeks Jensen 
- $R p=$ return portofolio pada periode $t$

- $\operatorname{Rf}=$ return pada investasi bebas resiko pada periode $t$

- $\quad \mathrm{Rm}=\mathrm{bp}=$ koefisien beta pasar.

Kriteria yang dapat digunakan adalah jika nilai indek Jensen posotif maka akan memberikan return yang lebih besar dari return harapannya, tetapi sebaliknya jika bernilai negatif.

Data yang sudah didapatkan dari laporan keuangan dalam bentuk ICMD selanjutnya diolah untuk mendeskripsikan metode Sharpe, Treynor dan Jensen. Penelitian ini menggunakan metode deskriptif dengan menginterpretasikan data yang diperoleh berdasarkan fakta-fakta yang tampak dalam kurun waktu penelitian sehingga diperoleh gambaran yang jelas tentang objek yang diteliti.

\section{Metode Penelitian}

Pendekatan yang di gunakan dalam penelitian ini adalah pendekatan kualitatif. Metode penelitian kualitatif digunakan untuk mendapatkan data yang mendalam, suatu data yang mengandung makna atau data yang sebenarnya. Penelitian kualitatif tidak semena-mena mencari kebenaran, tetapi pada pemahaman terhadap apa yang di teliti.

\section{Hasil dan Pembahasan}

Berdasarkan pengolahan data melalui program excel, didapatkan hasil sebagai berikut:

Tabel 1

\begin{tabular}{|c|c|c|}
\hline \multicolumn{3}{|c|}{ Sharpe Index } \\
\hline GGRM & HMSP & WIIM \\
\hline$-0,963042911$ & $-0,406055493$ & $-1,039683693$ \\
\hline
\end{tabular}

Berdasarkan tabel diatas, diketahui bahwa berdasarkan perhitungan dengan indek Sharpe diketahui bahwa perusahaan dengan kode HMSP memiliki nilai yang terbaik diantara kedua perusahaan lainnya, dengan demikian dapat disusun peringkat kinerja terbaik berdasarkan indek Sharpe adalah HMSP, GGRM dan WIIM.

Tabel 2

\begin{tabular}{|c|c|c|}
\hline \multicolumn{3}{|c|}{ Treynor Measure } \\
\hline GGRM & HMSP & WIIM \\
\hline & & - \\
$-0,174368363$ & $-0,06532$ & 0,120226543 \\
\hline
\end{tabular}

Berdasarkan tabel diatas, diketahui bahwa berdasarkan perhitungan dengan indek Treynor diketahui bahwa perusahaan dengan kode HMSP memiliki nilai yang terbaik diantara kedua perusahaan lainnya, dengan demikian dapat disusun 
peringkat kinerja terbaik berdasarkan indek Sharpe adalah HMSP, WIIM dan GGRM.

Tabel 3

\begin{tabular}{|c|c|c|}
\hline \multicolumn{3}{|c|}{ Jensen Alpha } \\
\hline GGRM & HMSP & WIIM \\
\hline & & - \\
$-0,04045$ & $-0,03905$ & 0,100889625 \\
\hline
\end{tabular}

Berdasarkan tabel diatas, diketahui bahwa berdasarkan perhitungan dengan indek Jensen diketahui bahwa perusahaan dengan kode HMSP memiliki nilai yang terbaik diantara kedua perusahaan lainnya, dengan demikian dapat disusun peringkat kinerja terbaik berdasarkan indek Sharpe adalah HMSP, GGRM dan WIIM.

\section{Kesimpulan}

Berdasarkan pembahasan di atas, diketahui bahwa menurut ketiga indek perhitungan yang digunakan untuk mengetahui kinerja perusahaan menghasilkan perusahaan yang sama yang memiliki kinerja terbaik yaitu perusahaan dengan kode HMSP, tetapi untuk peringkat berikutnya terdapat perbedaan antara perusahaan dengan kode GGRM dan WIIM, hal ini dimungkinkan terjadi karena ketiga ukuran kinerja portofolio di atas tidak terlepas dari kemungkinan terjadinya kesalahan dalam pengukuran. Tetapi setidaknya perhitungan tersebut menunjukkan akan lebih baik bagi investor untuk membeli saham HMSP sebagai pilihan pertama didalam pembentukan portofolionya.

\section{Referensi}

Hartono, Jogiyanto. (2003). Teori Portofolio dan Analisis Investasi, edisi Kelima. Yogyakarta: BPFE.

Manurung, Adler Haymans, 2000, "Mengukur Kinerja Portofolio", Usahawan, No 11 Nopember XXIX,h 41-46.

Sharpe, William F, Gordon J Alexander \& Jeffrey V Bailey.1995, Investment, Fifth Edition, Prentice Hal, Inc International Editions.

Statman (1987), Financial Management. Oxford University Press.

Tandelilin, Eduardus. 2010. Portofolio dan Investasi, Teori dan Aplikasi. Edisi Pertama. Yogyakarta : BPFE.

Wijaya, John Henry. "Implementasi Capital Asset Pricing Model (Capm) Dalam Penentuan Saham Efisien: Studi Pada Bank Bca, BRI, DAN BNI PERIODE 2012-2013." (2014). 
Wijaya, John Henry, 2015, Implementasi Analisis Kinerja Portofolio Saham Dengan Metode Sharpe, Treynor dan Jensen (Studi Kasus Saham Perusahaan Manufaktur 2014), JBME, Vol 14 No. 1 Mei 2015.

www.idx.com 